\title{
Young South Africans' views on, And Perceptions of, ABSTINENCE AND FAITHFULNESS
}

\section{Authors:}

Keitshepile G. Setswe

Khangelani Zuma ${ }^{1}$

\section{Affiliations:}

${ }^{1}$ Human Sciences Research

Council, Pretoria,

South Africa

\section{Correspondence to: \\ Keitshepile Setswe}

email:

gsetswe@hsrc.ac.za

\section{Postal address:}

HSRC, Private Bag X41,

Pretoria 0001, South Africa

\section{Keywords:}

abstinence; faithfulness; perceptions ;views; youth

\section{Dates:}

Received: 19 Jan. 2009

Accepted: 27 Oct. 2009

Published: 06 Aug. 2010

How to cite this article: Setswe, K.G. \& Zuma, K., 2009, 'Young South Africans' views on, and perceptions of, abstinence and faithfulness', Health SA Gesondheid 15(1), Art. \#414, 7 pages. DOI: 10.4102/hsag.v15i1.414

This article is available at:

http://www.hsag.co.za

(c) 2010. The Authors.

Licensee: OpenJournals Publishing. This work is licensed under the Creative Commons Attribution License.

\section{ABSTRACT}

The goals of the Abstinence and Be Faithful Among Youth (ABY) project were to enhance local responses among the youth in South Africa to prevent HIV infection through encouraging abstinence, faithfulness and avoidance of unhealthy sexual behaviour among youths over a five-year period. A quantitative baseline evaluation of the ABY project was conducted in five cities in South Africa. Data were collected from learners and youths just before the ABY intervention started at nine randomly selected sites in Johannesburg, Cape Town, Durban, Port Elizabeth and Mthatha using a three-stage cluster sampling design. In total, nine sites were randomly selected from a possible eighteen. At each of the data-collection points, data were collected from 60 participants. In total there were 27 data-collection points and 1620 respondents. Young people have strong views on abstaining from sexual intercourse, as $83 \%$ said that it was possible not to have sex for as long as you can. There was also strong support for abstinence, as $78.5 \%$ said that not having sex was the best way of preventing infection with HIV. In total, $68.1 \%$ of the youths said that the media had a positive influence on encouraging abstinence and $72.1 \%$ said role models could help them not to have sex, while $84.3 \%$ said that leadership and life skills workshops were helpful in encouraging them to abstain from sex. In total, $68.7 \%$ of young people said that the media encouraged faithfulness in relationships and $84.6 \%$ said that life skills workshops were helpful in encouraging them to remain faithful to one partner. Young people have strong views on and support for abstinence. They also have strong views on and perceptions of remaining faithful to one partner. These findings are a valuable guide to the views and perceptions of young people with respect to abstinence and faithfulness before interventions are implemented.

\section{OPSOMMING}

Die doel van die Abstinence and Be Faithful for Youth (ABY) projek was om die plaaslike reaksie onder jong mense te versterk ten einde MIV-infeksies te voorkom deur onthouding, getrouheid en vermyding van ongesonde seksuele gedrag onder die jeug oor ' $n$ vyfjaar-tydperk aan te moedig. ' $n$ Kwantitatiewe basislyn-evaluering van die ABY-projek is in vyf stede in Suid Afrika uitgevoer. Data is van leerders en jongmense by nege lukraak gekose plekke in Johannesburg, Kaapstad, Durban, Port Elizabeth en Mthatha met behulp van ' $n$ klustermonsternemingsontwerp in drie fases ingesamel kort voor die ABY-intervensie begin het. In totaal is nege plekke lukraak gekies uit 'n moontlike agtien. By elke data-insamelingspunt is data van 60 deelnemers verkry. In totaal was daar 27 data-insamelingspunte en 1620 respondente. Jongmense het sterk menings oor seksuele onthouding, aangesien $83 \%$ gesê het dat dit moontlik is om seksuele omgang vir so lank moontlik te vermy. Daar was ook sterk ondersteuning vir onthouding, aangesien $78 \%$ gesê het dat onthouding die beste voorkomingsmaatreël vir MIV-infeksie is. Wat die media betref, het $68.1 \%$ van die jongmense aangedui dat dit 'n positiewe invloed het om onthouding aan te moedig en $71.1 \%$ het aangedui dat rolmodelle hulle kan help om nie seks te beoefen nie, terwyl $84.1 \%$ aangedui het dat leierskaps- en lewensvaardigheidswerkswinkels hulle gehelp het om hulle van seks te onthou. In totaal het $68.7 \%$ van die jongmense aangedui dat dit getrouheid in vaste verhoudings aanmoedig en $84.6 \%$ het aangedui dat lewensvaardigheidswerkswinkels hulle aangemoedig het om getrou aan een persoon te wees. Jongmense het sterk menings oor onthouding en ondersteun dit ten sterkste. Hulle het ook sterk menings oor en persepsies van getrouheid aan een metgesel. Hierdie bevindinge is ' $n$ waardevolle riglyn oor jongmense se menings en persepsies rakende onthouding en getrouheid voordat intervensies geïmplementeer word.

\section{INTRODUCTION}

Young people bear the burden of South Africa's severe HIV epidemic, with $10.3 \%$ of 15 - to 24-year-olds infected with HIV nationally (Shisana et al. 2005). In response, research and interventions in South Africa address sexual risk behaviours among young people. Adolescent sexual behaviour creates problems such as an early commitment to a serious relationship, anxiety, guilt and fear, sexually transmitted infections (STIs), abortions, and single parenthood, which often leads to poor developmental outcomes for both mother and child (Abbott 2002).

A systematic review of factors that shape young people's sexual behaviour found that almost half of new HIV cases worldwide occur among people aged 15-24, making efforts to change sexual behaviour among youths a vital component in the fight against the HIV/AIDS pandemic. HIV-prevention campaigns targeting young people often encourage safer sex practices, such as condom use, as well as the distribution of condoms at no cost. Such campaigns often have disappointing results, even in areas where condoms are widely available and awareness about STIs is high (Marston \& King 2006).

Young people who have not had their sexual debut are encouraged to practice abstinence until they have established a lifelong monogamous relationship. For those youths who have initiated sexual activity, returning to abstinence is a primary message of prevention interventions.

Abstinence interventions encourage unmarried individuals to abstain from sexual activity as the best and only certain way to protect themselves from exposure to HIV and other STIs. Abstinence 
programmes are particularly important for young people, as approximately half of all new infections occur in the 15- to 24-year-old age group (UNAIDS 2004). A common perception is that abstinence education programmes focus narrowly on teaching youths the single message of abstaining from sexual activity before marriage.

In a survey conducted by the Kaizer Family Foundation (KFF) and the South African Broadcasting Corporation (SABC) among nearly 4000 South Africans aged 15-24 in 2006, an overwhelming majority $(96 \%)$ said that television and radio are generally doing a good job communicating about HIV / AIDS, and $89 \%$ said that television and radio has had a positive impact on their own understanding of HIV/AIDS and related sexual behaviours. About $50 \%$ said they talked with their partner about safer sex and more than $40 \%$ reported that they decided to change their sexual behaviour as a result of what they had learned about HIV / AIDS from the media (Kaizer Family Foundation 2007).

Sixty per cent of young South Africans named HIV / AIDS as the most important issue or problem facing young people their age in South Africa and three-quarters said they were personally concerned about becoming infected with HIV sometime in the next 10 years. Another South African youth survey found that, overall, two-thirds (67\%) of respondents reported that they have never had sexual intercourse, including nearly half $(47 \%)$ of $15-$ to 19 -year-olds and almost nine in ten (88\%) 20- to 24-year-olds (Pettifor et al. 2005).

A study on the teaching of abstinence in schools in South Africa, Thailand and Mexico, investigating whether abstinence messages were appropriate and effective, found that abstinence levels were $81 \%$ ( $87 \%$ in intervention female participants and $75 \%$ in intervention male participants) in South Africa. The reasons cited for abstaining from sex were that the individual was not ready, to protect his or her health and that friends were teasing him or her. Youths indicated that abstinence was a good choice because it protected against STIs and pregnancy (McCauley 2003).

A study on transitions to adulthood in South Africa found that adolescents were 3.9 times more likely to practice secondary abstinence in 2001 than in 1999. Girls were 9.3 times more likely to abstain while boys were 2.2 times more likely to abstain. The author concluded that life skills education had no impact on sexual behaviours such as multiple partners, delayed sexual debut or secondary abstinence (Liebowitz 2004).

Abstinence is a viable strategy for some groups but not for others. Faith-based organisations (FBOs) with a stronger history of involving themselves in the social, sexual and marital relationships between men and women were more credible in ensuring that their followers take seriously the strategy of abstinence. FBOs often deliver the message of faithfulness as a twin message alongside that of abstinence. The message of faithfulness, while somewhat less frequent, is targeted at married couples to encourage them to avoid the risks of infidelity and the chance that infidelity can lead to infection (Liebowitz 2004).

By 1995, a great majority of Ugandan women, namely $98.5 \%$, were reporting either abstinence or fidelity. Among the youth the proportion of 15- to 19-year-olds reporting that they had 'never had sex' rose from $31 \%$ to $56 \%$ among young men and from $26 \%$ to $46 \%$ among young women from 1989 to 1995 . In the Soroti district of Uganda, the proportion of 13- and 14-year-old learners reporting that they had 'never had sex' rose from 39\% to $95 \%$ among boys and from 66 to $98 \%$ among girls from 1994 to 2001 (Green 2003a).

In the national South African population-based survey of 2005, $40 \%$ of male and $25 \%$ of female South African youths aged 15 24 reported having more than one concurrent sexual partner (Shisana et al. 2005)
A survey to examine American teenagers' attitudes towards sexual activity outside of marriage found that about twothirds of teenage boys $(62.4 \%)$ and girls $(67.5 \%)$ aged $15-19$ disapproved of sexual activity among unmarried 16-year-olds (Groves et al. 2005).

Without being prompted, $23 \%$ of adolescent women and $28 \%$ of adolescent men said they knew that abstinence was a way of preventing HIV/AIDS. A slightly higher proportion of adolescent women than of adolescent men ( $32 \%$ vs $28 \%$ ) mentioned monogamy as a preventive strategy (Bankole et al. 2007).

Internationally, a number of interventions have proven successful in increasing abstinence until marriage, delaying first sex and achieving 'secondary abstinence' (that is, returning to abstinence) among sexually experienced youths. These interventions promote, firstly, abstinence from sexual activity as the most effective and only certain way to avoid HIV infection, secondly, the development of skills for practicing abstinence and, finally, the importance of abstinence in eliminating the risk of HIV transmission amongst unmarried individuals. They also include the decision of unmarried individuals to delay a sexual debut until marriage and the adoption of social and community norms that support this delay until marriage and that denounce cross-generational sex, transactional sex, as well as rape, incest and other forced sexual activities (Family Health International 2002).

In a review of the abstinence programmes in the USA (Di Censo 2002), pregnancy rates among the partners of young male participants were no lower than those among the partners of non-participants. Similarly, the effectiveness of abstinence as a long-term strategy, particularly for young people, was refuted by a study that reported that not only was the 'virginity pledge' broken by more than $60 \%$ of the pledgers, but $55 \%$ who reported keeping their virginity admitted to engaging in risky forms of non-vaginal sex (Lipsitz, Bishop \& Robinson 2003).

Age at first sex is an important indicator of sexual risk, as it marks the onset of one's potential exposure to infection, is a risk factor for acquiring HIV and is a key indicator for monitoring the response to the HIV epidemic among youths. Delaying the first sexual encounter can have a significant impact on the health and well-being of adolescents and on the progress of the HIV/ AIDS epidemic in communities. In many of the countries hardest hit by HIV and AIDS, sexual activity begins early and prior to marriage. Surveys show that, on average, slightly more than $40 \%$ of women in sub-Saharan Africa have had premarital sex before age 20; among young men, sex before marriage is even more common. A significant minority of youths experience first sex before age 15 (Family Health International 2002).

Be faithful interventions encourage individuals to practice fidelity in marriage and other sexual relationships as a critical way to reduce one's risk of exposure to HIV. Once a person begins to have sex, the fewer lifetime sexual partners he or she has, the lower the risk of contracting or spreading HIV or another STI. Be Faithful interventions promote:

- the elimination of casual sexual partnerships

- the development of skills for sustaining marital fidelity

- the importance of mutual faithfulness with an uninfected partner in reducing the transmission of HIV among individuals in long-term sexual partnerships

- HIV counselling and testing with their partner for those couples who do not know their HIV status

- endorsement of social and community norms supportive of refraining from sex outside of marriage, partner reduction and marital fidelity, by using strategies that respect and respond to local cultural customs and norms and to the adoption of social and community norms that denounce cross-generational sex, transactional sex as well as rape, incest and other forced sexual activities (Stoneburner \& Low-Beer 2004). 
At the June 2001 United Nations General Assembly Special Session (UNGASS) on HIV/AIDS, member countries set two ambitious goals specifically related to young people. The first goal was to reduce HIV prevalence among young people aged $15-24$ by $25 \%$ in the most affected countries by 2005 and by $25 \%$ globally by 2010 . The second goal was to ensure that $90 \%$ of young people aged 15-24 have the knowledge, education, life skills and services to protect themselves from HIV by 2005 and $95 \%$ of them by 2010 (UNGASS 2001).

The goal of the Abstinence and Be Faithful Among Youth (ABY) interventions implemented by the Olive Leaf Foundation in South Africa represented a response to the UNGASS goals by enhancing local responses among the youth to prevent HIV infection through encouraging abstinence, faithfulness and avoidance of unhealthy sexual behaviour among and affecting youths (Tshabalala 2005).

ABY interventions promoted dignity and self-worth, the importance of abstinence in reducing the transmission of HIV, the importance of delaying sexual activity until marriage, the development of skills for practicing abstinence (and, where appropriate, secondary abstinence), the elimination of casual sexual partnerships, the importance of marriage and mutual faithfulness in reducing the transmission of HIV among individuals in long-term relationships and the importance of HIV counselling and testing as a way of significantly reducing the risk of HIV infection (Tshabalala 2005).

\section{RESEARCH OBJECTIVES}

The specific objectives of this study were to assess young people's views on and perceptions of:

- abstinence and faithfulness as HIV-preventive approaches

- the role of the media and role models in encouraging abstinence and faithfulness

- the role of life skills programmes and workshops in encouraging abstinence and faithfulness.

\section{RESEARCH METHOD AND DESIGN}

\section{Population sampling}

The ABY interventions were evaluated using a cross-sectional survey among learners and youths. The survey was conducted in randomly selected schools, churches and community youth centres among learner and youth participants. The sampling frame in Table 1 indicates where data were collected in each of the five cities implementing $A B Y$ interventions.

A three-stage cluster sampling design was used to select a sample for this study. In the first stage, there were $20 \mathrm{ABY}$ intervention sites in five cities - Johannesburg, Cape Town, Durban, Port Elizabeth and Mthatha. Eleven sites were randomly selected for the pre- and post-intervention surveys. Of these, two sites were randomly selected from the eight sites in Johannesburg, two were randomly selected from four sites in Cape Town, two were randomly selected from three sites in Durban, one was randomly selected from two sites in Port Elizabeth and two were randomly selected from three sites in Mthatha.

In the second stage, three data-collection places were identified in each of the evaluation sites. These were a primary school (for learners aged 10-14 years), a high school (for learners aged 1519 years) and a site for out-of-school youths (aged 20-24 years). At each of the evaluation points, data were collected from 60 respondents in the third stage. In all, data were collected from 1620 learners and youths at 27 evaluation points.

All learners and youths who were located in the sites indentified for the ABY interventions in the five cities qualified for inclusion in the baseline survey. Learners and youths who were located in the sites not identified for the ABY intervention were excluded from the study.

Respondents were finally selected using a take-it-all approach at each evaluation point. This means that all learners and youths who were available in the sampled grade on the day of the survey were asked to participate in the study.

\section{Data collection}

The baseline survey was conducted on the first day the intervention was going to be introduced to participants. Data from sampled evaluation sites and individuals were collected using two types of questionnaires - one for learners aged 10-14 years and another for learners/youths aged 15-24 years. Key questions centred on awareness and knowledge of HIV/ AIDS, attitudes towards people living with HIV/AIDS, views on dating, relationships, sexuality and pregnancy, views on abstinence and faithfulness, the role of the media, role models and workshops in encouraging abstinence and faithfulness, and the effect of peer-group pressure and violence on abstinence and faithfulness.

Just before the ABY intervention was introduced, the evaluation team members obtained consent from parents and assent from learners at schools and then distributed relevant questionnaires to participants, explained how they should be filled out and then collected the completed questionnaires. The study was approved by the ethics review team of the Olive Leaf Foundation.

\section{Statistical analysis}

The main outcome of the data analysis is an ordinal variable with responses 'strongly disagree', 'disagree', 'unsure', 'agree' and 'strongly agree'. Scores of one to five were assigned to the outcome variable, with one indicating strongly disagree and five indicating strongly agree. A descriptive analysis was carried out using Statistical Package for Social Sciences (SPSS) version 17. The correlation and trend analysis was conducted in Statistical Analysis Systems (SAS) version 9.1. Unweighted data analysis was conducted. Pearson product-moment correlation is reported to indicate the strength and direction of association. A $p$-value less or equal to five per cent is used to indicate statistical significance. All $p$-values are based on a chi-squared test.

\section{RESULTS}

A total of 1620 learners and youths were eligible to participate in the survey. Only 1310 young South Africans aged 10-24 years agreed to participate, giving a response rate of $81 \%$. Some of the reasons for non-participation by $19 \%$ of sampled participants were that they were not interested or they simply did not return the questionnaires.

TABLE 1

Sampling for baseline evaluation of ABY interventions in South Africa

\begin{tabular}{lllll}
\hline City & Number of intervention sites & Number of evaluation sites & Number of evaluation points & Number of participants \\
\hline Johannesburg & 8 & 2 & $3 \times 2=6$ & $3 \times 2=6$ \\
Cape Town & 4 & 2 & $3 \times 2=6$ & $60 \times 6=360$ \\
Durban & 3 & 2 & $3 \times 1=3$ & $60 \times 6=360$ \\
Port Elizabeth & 2 & 1 & $3 \times 2=6$ & $60 \times 3=180$ \\
Mthatha & 3 & 2 & $\mathbf{2 7}$ points & $60 \times 6=360$ \\
\hline Total & $\mathbf{2 0}$ & $\mathbf{1 1}$ & $\mathbf{1 6 2 0}$ \\
\hline
\end{tabular}


TABLE 2

Young people's views on abstinence

\begin{tabular}{|c|c|c|c|c|c|c|c|}
\hline \multirow[t]{2}{*}{ Variable } & \multirow[t]{2}{*}{ Total } & \multicolumn{5}{|c|}{ It is possible to not have sex for as long as you can (\%) } & \multirow[t]{2}{*}{ Trend test $p$-value } \\
\hline & & Strongly disagree & Disagree & Unsure & Agree & Strongly agree & \\
\hline Overall & 1122 & 1.7 & 7.1 & 8.2 & 22.5 & 60.5 & \\
\hline \multicolumn{8}{|l|}{ Sex } \\
\hline Male & 482 & 2.3 & 7.7 & 11 & 25.7 & 53.3 & $<0.001$ \\
\hline Female & 640 & 1.3 & 6.7 & 6.1 & 20 & 65.9 & \\
\hline \multicolumn{8}{|l|}{ Age in years } \\
\hline 10 to 14 & 423 & 1 & 11.58 & 10.64 & 24.59 & 52.25 & \\
\hline 15 to 19 & 609 & 1.97 & 4.6 & 7.22 & 22.5 & 63.71 & $<0.001$ \\
\hline 20 to 24 & 90 & 3.33 & 3.33 & 3.33 & 12.22 & 77.78 & \\
\hline \multicolumn{8}{|l|}{ City } \\
\hline Johannesburg & 158 & 1.27 & 5.06 & 5.06 & 24.05 & 64.56 & \\
\hline Cape town & 432 & 2.78 & 6.71 & 11.81 & 23.38 & 55.32 & \\
\hline Durban & 151 & 3.31 & 8.61 & 5.3 & 23.18 & 59.6 & \\
\hline Port Elizabeth & 333 & 0 & 8.71 & 6.31 & 21.02 & 63.96 & 0.129 \\
\hline Mthatha & 48 & 0 & 2.08 & 8.33 & 16.67 & 72.92 & \\
\hline
\end{tabular}

\section{ETHICAL CONSIDERATIONS}

The study was conducted in line with principles of ethical research involving human subjects. These principles include special attention to communicating the aims of the study and the rights of people participating in the study such as informed consent and assent where necessary and confidentiality. The study proposal, tools for data collection and consent documents were reviewed and approved by the Ethics Committee at Hope Worldwide.

Slightly more young women $(56.5 \%)$ than young men $(43.5 \%)$ agreed to be interviewed. The majority of the respondents were between the ages of 15-19 years (48.0\%) followed by those aged $10-14$ years $(44.7 \%)$ and the least were aged $20-24$ years. About one-third of the respondents $(33.8 \% ; 443)$ were from the Eastern Cape, with a quarter $(25.6 \% ; 335)$ from Port Elizabeth and $8.2 \%$ (108) from Mthatha. Another third (33.1\%; 434) of the respondents were from Cape Town in the Western Cape, 20\% (262) were from Johannesburg in Gauteng, while 13.1\% (171) were from Durban in KwaZulu-Natal.

\section{VALIDITY AND RELIABILITY}

Trustworthiness in this study was measured through reliability to determine the consistency or repeatability of the questionnaire and through validity to ensure that we were measuring what we wanted to measure. The questionnaire for this study was pilot-tested in a small sample of young people in Soweto to test it for validity. It was also used in the pre-intervention and post-intervention surveys. The use of the same questionnaire in the post-intervention survey offered an opportunity for it to be tested for reliability. This test-retest reliability was an opportunity to determine whether repeating the questionnaire under the same conditions produced the same results.

\section{Views on abstinence}

Young people had strong views on abstaining from sexual intercourse. A significant number of young people $(83 \%)$ said that it is possible not to have sex for as long as you are able to. Only $8.8 \%$ of the young people thought it is not possible to not have sex for as long as you can. About $8.2 \%$ of the respondents were unsure whether it was possible or not to not have sex for as long as you can (see Table 2). The results show that few respondents strongly disagreed that it is possible to not have sex for as long as you can with a linear increase towards strongly agreeing. Comparing young men to young women, there is a strong association between gender and whether it is possible not to have sex for as long as you can (Pearson product-moment correlation $[r]=0.11)$. Young men were more likely than young women to be in agreement. Similarly, the older the respondents, the more likely they were to agree that it is possible to not have sex for as long as you can $(r=0.14)$. However, there was no association between the cities from which the respondents came.

The 20- to 24-year-olds had the strongest views $(77.8 \%)$ on not having sex, followed by the 15 - to 19 -year-olds at $52.25 \%$. More young men $(65.9 \%)$ than young women $(53.3 \%)$ had stronger views on not having sex as long as you can.

There was strong support for abstinence as a way of preventing infection with HIV. In total, $78.5 \%$ of young people believed that not having sex is the best way of preventing infection with HIV. This is in contrast to only $9.6 \%$ who disagreed or strongly disagreed with the statement. Regarding their views on abstinence, $11.7 \%$ of respondents were unsure. The support for abstinence did not differ significantly between young men and young women (see Table 3). However, the older the respondents, the greater the significant likelihood that they were to support abstinence as a way of preventing HIV infection ( $p$-value = 0.006). The results did not differ between the cities.

\section{Role of the media in encouraging abstinence}

Significantly more young people believed that the media had an important role in encouraging abstinence. A majority of the young people $(68.1 \%)$ believed that newspapers, television and radio had a positive influence in encouraging abstinence, while only $14.6 \%$ disagreed or strongly disagreed with the statement. Of the young people, $17.3 \%$ were unsure about the role of the media in encouraging abstinence. There was no association between gender and whether the media play a positive influence in encouraging abstinence (see Table 4). However, there was a significant negative correlation between the role of the media and age $(r=-0.12 ; p<0.001)$. The older the respondents, the less likely they were to agree that newspapers, television and radio have a positive influence in encouraging abstinence.

\section{Role models, leadership workshops and the media}

Role models play a important role in impacting young people with regard to abstinence. Of the respondents, $72.1 \%$ said role models can help young people abstain from sex, while $14.9 \%$ said role models cannot help young people to abstain from sex (see Table 5). A significantly large number of respondents $(84.3 \%)$ said that leadership and life-skills workshops are helpful in encouraging young people to abstain from sex. Only $6.6 \%$ said that leadership and life skills workshops were not encouraging abstinence among young people. Eight per cent of the respondents were unsure of the role of leadership and life skills workshops in encouraging abstinence among young people. An overwhelming majority of respondents (84.6\%) said that life skills workshops were helpful in encouraging young people to remain faithful to one partner. Of the respondents, $8.2 \%$ either 
TABLE 3

Young people's views on the role of abstinence in preventing infection with HIV

\begin{tabular}{|c|c|c|c|c|c|c|c|}
\hline \multirow[t]{2}{*}{ Variable } & \multirow[t]{2}{*}{ Total } & \multicolumn{5}{|c|}{ Not having sex is the best way of preventing infection with HIV (\%) } & \multirow[t]{2}{*}{ Trend test $p$-value } \\
\hline & & Strongly disagree & Disagree & Unsure & Agree & Strongly agree & \\
\hline Overall & 1113 & 1.98 & 7.91 & 11.68 & 20.49 & 57.95 & \\
\hline \multicolumn{8}{|l|}{ Sex } \\
\hline Male & 480 & 1.67 & 8.13 & 15 & 21.25 & 53.96 & \\
\hline Female & 633 & 2.21 & 7.74 & 9.16 & 19.91 & 60.98 & 0.063 \\
\hline \multicolumn{8}{|l|}{ Age in years } \\
\hline 10 to 14 & 421 & 0.95 & 9.03 & 13.54 & 24.23 & 52.26 & \\
\hline 15 to 19 & 602 & 2.82 & 7.81 & 11.63 & 17.94 & 59.8 & \\
\hline 20 to 24 & 90 & 1.11 & 3.33 & 3.33 & 20 & 72.22 & 0.006 \\
\hline \multicolumn{8}{|l|}{ City } \\
\hline Johannesburg & 148 & 1.35 & 4.73 & 9.46 & 22.3 & 62.16 & \\
\hline Cape town & 433 & 3 & 8.31 & 14.09 & 19.4 & 55.2 & \\
\hline Durban & 151 & 4.64 & 7.95 & 8.61 & 21.19 & 57.62 & \\
\hline Port Elizabeth & 333 & 0 & 8.11 & 9.31 & 22.22 & 60.36 & \\
\hline Mthatha & 48 & 0 & 12.5 & 22.92 & 10.42 & 54.17 & 0.757 \\
\hline
\end{tabular}

TABLE 4

Young people's views on the role of the media in encouraging abstinence

\begin{tabular}{|c|c|c|c|c|c|c|c|}
\hline \multirow[t]{2}{*}{ Variable } & \multirow[t]{2}{*}{ Total } & \multicolumn{5}{|c|}{ Newspapers, television and radio have a positive influence in encouraging abstinence (\%) } & \multirow[t]{2}{*}{ Trend test $p$-value } \\
\hline & & Strongly disagree & Disagree & Unsure & Agree & Strongly agree & \\
\hline Overall & 1113 & 1.98 & 7.91 & 11.68 & 20.49 & 57.95 & \\
\hline \multicolumn{8}{|l|}{ Sex } \\
\hline Male & 479 & 3.76 & 9.19 & 17.75 & 36.95 & 32.36 & \\
\hline Female & 633 & 5.53 & 10.27 & 16.9 & 34.28 & 33.02 & 0.385 \\
\hline \multicolumn{8}{|l|}{ Age in years } \\
\hline 10 to 14 & 421 & 3.33 & 10.45 & 10.69 & 34.92 & 40.62 & \\
\hline 15 to 19 & 601 & 5.66 & 9.82 & 19.97 & 36.27 & 28.29 & \\
\hline 20 to 24 & 90 & 5.56 & 6.67 & 30 & 32.22 & 25.56 & 0.001 \\
\hline \multicolumn{8}{|l|}{ City } \\
\hline Johannesburg & 148 & 7.43 & 17.57 & 14.19 & 34.46 & 26.35 & \\
\hline Cape town & 433 & 6.7 & 6.47 & 15.94 & 34.18 & 36.72 & \\
\hline Durban & 150 & 8.67 & 10.67 & 8.67 & 46.67 & 25.33 & \\
\hline Port Elizabeth & 333 & 0 & 9.91 & 22.52 & 33.03 & 34.53 & \\
\hline Mthatha & 48 & 0 & 12.50 & 29.17 & 31.25 & 27.08 & 0.067 \\
\hline
\end{tabular}

disagreed or strongly disagreed that workshops encouraged faithfulness, while the same ratio of respondents were unsure of the role of workshops in encouraging faithfulness (Table 5).

Young people have significantly strong views on the role of the media in encouraging faithfulness in relationships. The majority of the young people $(78.4 \%)$ believed that newspapers, television and radio encouraged faithfulness in relationships, while only $10.0 \%$ disagreed or strongly disagreed with the statement. In total, $11.7 \%$ of the respondents were unsure of the media's role in encouraging faithfulness in relationships. Young men and young women did not differ significantly in their response to whether the media encourage faithfulness in relationships (see Table 6). There was a significant negative correlation $(r=-0.13$; $p$-value $<0.001)$ between age and the response to whether the media encourage faithfulness in relationships. The older the respondents, the less likely they were to agree or strongly agree that the media encourage faithfulness in relationships.

\section{DISCUSSION}

The $83 \%$ support for abstinence in this study was comparable to $81 \%$ abstinence levels among intervention schoolchildren in South Africa (McCauley 2003). Although the ABY survey was conducted before the intervention was implemented, it is a positive approach to have participants with strong views before the intervention starts. On the other hand, strong views on abstinence may not necessarily translate into positive behavioural practice.
The support for abstinence did not differ significantly between young men and young women. This is encouraging, since it is not only young men or young women who support abstinence, but both sexes.

The findings that $83 \%$ of young people in the ABY survey supported abstinence were better than the findings of a study in Uganda, where the proportion of 15- to 19-year-olds reporting that they had abstained was $56 \%$ among young men and $46 \%$ among young women (Singh, Darroch \& Bankole 2004). The findings are however comparable to the high rate of sexual abstinence among younger adolescents in the Soroti district of Uganda, where the proportion of 13- and 14-year-olds reporting that they had abstained rose to $95 \%$ among boys and $98 \%$ among girls (Green 2003b).

Two-thirds (67\%) of young South Africans in the KFF survey reported that they have had sexual intercourse, including nearly half $(47 \%)$ of 15 - to 19 -year-olds and almost nine in ten $(88 \%)$ 20 - to 24-year-olds (Kaizer Family Foundation 2007). It can be estimated that the abstinence levels are about 33\%. These abstinence levels are significantly lower than self-reports in this ABY survey.

About $65 \%$ of 15- to 19-year-olds in an American youth survey disagreed that unmarried 16-year-olds should have sexual intercourse. These findings are also significantly lower than selfreports in the ABY survey (Sinding 2005). 
TABLE 5

Young people's views on role models and leadership workshops

\begin{tabular}{|c|c|c|c|c|c|c|}
\hline & Total & Strongly disagree & Disagree & Unsure & Agree & Strongly agree \\
\hline Role models can help young people not to have sex & 363 & 1.4 & 13.5 & 12.9 & 33.3 & 38.8 \\
\hline Leadership and workshops encourage abstinence & 1113 & 1.6 & 6 & 8 & 28.8 & 55.5 \\
\hline Leadership and workshops encourage faithfulness & 759 & 1.1 & 6.1 & 8.2 & 34 & 50.6 \\
\hline
\end{tabular}

The abstinence levels of $87 \%$ in intervention female youths and $75 \%$ in intervention male youths in McCauley (2003) were comparable to $78.5 \%$ support for abstinence in this survey.

In short, the findings in the Ugandan study (Groves et al. 2005), the KFF survey (Kaizer Family Foundation 2007) and the abstinence study (McCauley 2003) were in line with findings in this ABY survey. There were high levels of abstinence or strong support for abstinence as a way of preventing infection with HIV. However, the findings in the ABY survey were better than the findings of another study in Uganda conducted by the World Bank (Singh, Darroch \& Bankole 2004).

The $68.1 \%$ influence of the media on abstinence and faithfulness was significantly lower than in the KFF survey, which found that $96 \%$ of young South Africans said that television and radio were generally doing a good job communicating about HIV/AIDS, and $89 \%$ said that television or radio had a positive impact on their own understanding of HIV/AIDS and related sexual behaviours (Kaizer Family Foundation 2007).

An overwhelming $90 \%$ of young South Africans in the KFF survey indicated that broadcast media have a critical role to play in HIV prevention in South Africa. Again, 83\% of respondents said that national HIV/AIDS prevention and education campaigns were very effective in teaching young people about HIV/AIDS (Kaizer Family Foundation 2007). Both are significantly more than the $68.7 \%$ obtained in the ABY survey. However, the older the respondents, the less likely were they to agree that newspapers, television and radio have a positive influence in encouraging abstinence. There is a need for further research on the role of the media in encouraging young people aged 15-24 to consider abstinence as an option in the prevention of HIV.

A study on transitions to adulthood in South Africa concluded that life-skills education had no impact on sexual behaviours such as multiple partners, delayed sexual debut or secondary abstinence. This is contrary to findings in the ABY study, where an overwhelming number of young South Africans said that life skills encouraged them to remain faithful to one partner (Liebowitz 2004)

\section{LIMITATIONS OF THE STUDY}

The major limitation of the survey method used in this study was that it relied on a self-report method of data collection. Intentional deception, poor memory, or misunderstanding of the question could all have contributed to inaccuracies in the data. This was particularly true for questions probing behaviour as compared to generally accepted norms of society. Young people were unwilling to indicate they had engaged in behaviour not accepted by their peers or parents.

Furthermore, this method is descriptive, not explanatory and, therefore, could not offer any insights into cause-and-effect relationships.

\section{RECOMMENDATIONS}

A conclusive answer to whether the abstinence and faithfulness interventions are effective will require larger, more rigorous experimental studies.

Firstly, it is recommended that randomised controlled trials be conducted to compare young people who are in ABY interventions to controls. Randomised controlled trials are preferable as they are a 'gold standard' and provide comparison between those receiving an intervention and those receiving another or no intervention. Alternatively, it would be helpful to have cohort or longitudinal studies that follow up participants who use abstinence and fidelity as an intervention over a long period of time and to compare them to similar groups.

Secondly, it is recommended that systematic reviews and metaanalyses of research done in this area should provide evidence or otherwise of the effectiveness of abstinence and faithfulness in reducing HIV prevalence. Evidence-based research will bury any uncertainties and provide programme implementers with targeted information they can use for their interventions.

\section{CONCLUSION}

Key findings in this study were that young South Africans had strong views on abstaining from sexual intercourse. There was strong support for abstinence as a way of preventing infection with HIV among young South Africans. They also had strong views on, and perceptions of, remaining faithful to one partner.

TABLE 6

Views on the role of newspapers, television and radio in encouraging faithfulness, by gender

\begin{tabular}{|c|c|c|c|c|c|c|c|}
\hline \multirow[t]{2}{*}{ Variable } & \multirow[t]{2}{*}{ Total } & \multicolumn{5}{|c|}{ The media encourage faithfulness in relationships (\%) } & \multirow[t]{2}{*}{ Tren test $p$-value } \\
\hline & & Strongly disagree & Disagree & Unsure & Agree & Strongly agree & \\
\hline Overall & 1113 & 1.98 & 7.91 & 11.68 & 20.49 & 57.95 & \\
\hline \multicolumn{8}{|l|}{ Sex } \\
\hline Male & 479 & 2.51 & 10.86 & 17.33 & 37.37 & 31.94 & \\
\hline Female & 634 & 3.00 & 11.20 & 17.51 & 38.01 & 30.28 & 0.538 \\
\hline \multicolumn{8}{|l|}{ Age in years } \\
\hline 10 to 14 & 422 & 2.13 & 9.48 & 14.93 & 35.55 & 37.91 & \\
\hline 15 to 19 & 601 & 2.83 & 10.98 & 19.3 & 39.27 & 27.62 & \\
\hline 20 to 24 & 90 & 5.56 & 18.89 & 16.67 & 37.78 & 21.11 & $<0.001$ \\
\hline \multicolumn{8}{|l|}{ City } \\
\hline Johannesburg & 148 & 6.08 & 20.95 & 17.57 & 37.16 & 18.24 & \\
\hline Cape town & 433 & 2.54 & 7.62 & 18.48 & 35.80 & 35.57 & \\
\hline Durban & 150 & 7.33 & 15.33 & 16 & 33.33 & 28 & \\
\hline Port Elizabeth & 334 & 0 & 9.28 & 16.77 & 43.71 & 30.24 & $<0.001$ \\
\hline Mthatha & 48 & 0 & 10.42 & 16.67 & 29.17 & 43.75 & \\
\hline
\end{tabular}


Significantly more young people believe that the media have an important role in encouraging abstinence and that role models play a significantly important role in impacting young people on abstinence. Again, a significantly large number of young South Africans said that leadership and life skills workshops were helpful in encouraging them to abstain from sex.

Young South Africans had strong views on the role of the media in encouraging faithfulness in relationships, although this was lower than in the KFF youth survey where $90 \%$ indicated that broadcast media have a critical role to play in HIV prevention in South Africa. An overwhelming number of young South Africans said that life skills training encouraged them to remain faithful to one partner.

These findings are a valuable guide on the views and perceptions of young people before $\mathrm{ABY}$ interventions are implemented in South Africa.

Research studies that claim that abstinence and faithfulness approaches were not effective in the prevention of HIV / AIDS cite several interventions as reasons for the decline in HIV prevalence. These include, for example, condom distribution and use, cleaner needles and a combination of abstinence, be faithful and condomise (ABC).

\section{REFERENCES}

Abbott, D., 2002, 'Sexual abstinence: The best choice for adolescents', The ups $\mathcal{E}$ downs of adolescence, Youth Development, University of Nebraska Cooperative Extension, viewed 28 March 2007, from http://ianrwww. unl.edu/ianr/fcs/upsdowns/

Bankole, A., Singh, S., Woog, V. \& Wulf, D., 2007, 'Risk and protection: Youth and HIV/AIDS in sub-Saharan Africa', Alan Guttmacher Foundation, viewed 18 February 2007, from http://www.guttmacher.org/pubs/riskandprotection.pdf

Di Censo, A., Guyatt, G., Wilan, A. \& Griffith, L., 2002, 'Interventions to reduce unintended pregnancies among adolescents: Systematic review of randomized controlled trials', British Medical Journal 324, 1426-1435.

Family Health International, 2002, 'Abstinence: An moption for adolescents: Counseling of adolescents should include both abstinence and the use of contraceptive methods', Network 22(1), 1-4, viewed 28 March 2007, from http://www.fhi.org/ en/RH/Pubs/Network/v22_1/index.htm

Green, E.C., 2003a, 'HIV/AIDS, TB, and Malaria: Combating a global pandemic', presentation to the Subcommittee on Health, 20 March, viewed 30 March 2007, from http://energycommerce. house.gov/108/Hearings/03202003hearing832/Green1379.htm

Green, E.C., 2003b, Rethinking AIDS prevention: Learning from successes in developing countries, Greenwood Press, Boston.

Groves, R.M., Austin, E.W., Axinn, W., Couper M.P., Lepkowski, J.M. \& Hoelter, L., 2005, National Survey of Family Growth (NSFG), National Centre for Health Statistics, Hyattsville.
Kaizer Family Foundation, 2007, Young South Africans, broadcast media, and HIV/AIDS awareness: Results of a national survey, Johannesburg, South Africa.

Liebowitz, J., 2004, FBOs and HIV/AIDS in Uganda and KZN: Final report, Health Economics and AIDS Research Division (HEARD), viewed 12 February 2007, from http://www. ukzn.ac.za/heard/research/ResearchReports/2004/ FBO\%20Final\%20report\%202004.pdf

Lipsitz, A., Bishop, P.D. \& Robinson, C., 2003, 'Virginity pledges: Who takes them and how well do they work?', presentation at the annual convention of the American Psychological Society, Atlanta, GA, 31 May.

Marston, C. \& King, E., 2006, 'A systematic review of factors that shape young people's sexual behaviour', Lancet 4, 368(9547), 1581-1586.

McCauley, A., 2003, 'Teaching abstinence in schools: Findings from Horizons studies', Horizons, viewed 12 February 2007, from http://www.fhi.org/NR/ rdonlyres/odqe7lvtixrkhlz6sisuhlupmftsmvpiomr2en/ McCauleyPowerPoint.pps

Pettifor, A.E., Rees, H.V., Kleinschmidt, I., Steffenson, A.E., MacPhail, C., Hlongwa-Madikizela, L. et al., 2005, 'Young people's sexual health in South Africa: HIV prevalence and sexual behaviors from a nationally representative household survey', AIDS 19, 1525-1534.

Shisana, O., Rehle, T., Simbayi, L.C., Parker, W., Zuma, K., Bhana, A., Connoly, C., Jooste, S. \& Pillay, V., 2005, South African national HIV prevalence, HIV incidence, behaviour and communication survey, HSRC Press, Cape Town.

Sinding, S.W., 2005, 'Does 'CNN' (Condoms, Needles, Negotiation) work better than 'ABC' (Abstinence, Being Faithful and Condom Use) in attacking the AIDS epidemic?' International Family Planning Perspectives, March 31(1), viewed 4 April 2007, from http://www.agi-usa.org/pubs/ journals/3103805.html

Singh, S., Darroch, J.E. \& Bankole, A., 2004, 'A, B and C in Uganda: The roles of abstinence, monogamy and condom use in HIV decline', Reproductive Health Matters 12(23), 129-131.

Stoneburner, R.L. \& Low-Beer, D., 2004, 'Population-level HIV declines and behavioural risk avoidance in Uganda', Science 304(5671), 714-718.

Tshabalala, M., 2005, Proposal on enhancing local responses to HIV/AIDS prevention through abstinence, faithfulness and the reduction of harmful sexual behaviors for youth and other groups in five African countries, Olive Leaf Foundation, Johannesburg.

UNAIDS, 2004, Report of the global AIDS epidemic: 4th Global Report, Joint United Nations AIDS Program, Geneva.

UNGASS, 2001, United Nations General Assembly Special Session on HIV/AIDS, United Nations, New York. 